\title{
A Study on the Effects of FTA and Economic Integration on Throughput of Korea and China
}

\author{
A-Rom Kim, Jing Lu \\ Transportation Management Colleague, Dalian Maritime University, Dalian, China \\ Email: arkim@dlmu.edu.cn
}

Received 9 April 2016; accepted 23 April 2016; published 27 April 2016

Copyright (C) 2016 by authors and OALib.

This work is licensed under the Creative Commons Attribution International License (CC BY). http://creativecommons.org/licenses/by/4.0/

(c) (i) Open Access

\begin{abstract}
Trade relation of Korea and China has been growing explosively since the establishment of diplomatic relations in 1992. Now, China is important to the role of market in Korea. Therefore, it is very important to develop economy and trade relations. So in this study, we analyzed the impacts of FTA and economic integration on trade value using HS 85's panel data of 45 countries trading with Korea from 1992 until 2013 by gravity model. It can be inferred how many impacts of Korea and China's FTA on throughput. As a result, GDP and population were accorded with the basic gravity model; there was statistical significance in trade index (export similarity index; ESI, export and import price index) except trade complementarity index (TCI) as trade diversion effects. Finally, we proved trade-generating effect about FTA and economic integration as trade creation effects.
\end{abstract}

\section{Keywords}

Gravity Model, FTA, Economic Integration, Trade Index, Trade Diversion Effect, Trade Creation Effect

Subject Areas: Economics, Public Economics, Social Issues and Public Policy

\section{Introduction}

Because of geographical characteristics, China has a close relationship with Korea in history and culture. Now, China is important to the role of market in Korea. Trade relation of Korea and China has been growing explosively since the establishment of diplomatic relations in 1992.

The radical economic relationship with China is being expanded increasingly. China is ranked No. 1 trading partner of Korea, and Korea is ranked No. 4 trading partner of China. Therefore, it is very important to develop 
economy and trade relations. Reflecting these phenomena, in Korea, it is growing interest in regional trade agreement (RTA) of Korea and China. There are many private and government studies.

Therefore, in this study, we analyzed an extension of the previous research, took advantage of the export-import price index and analyzed the effect of the elimination of tariffs and the trade value among the factors that can affect. Tariff can be changed in the short term through free trade agreement. We also analyzed impacts of economic integration. GDP, productivity, population and geographical environment are fixed in the short term. It is limited to measure effect of regional trade agreement. However, according to the elimination of tariffs, export-import price index's short term effect can be predicted clearly. In this current situation, the market is rapidly cooled. It can say it is the way for expanding of trade value and activation of economy in the short term.

In addition, as mentioned earlier, economic environment will be changed as the formation of regional economic block like EU in the flow of the global economy. Therefore, Korea and China can form regional economic block as an important role of global economy based on sharing history and regional adjacency.

In this study, we analyzed the impacts of FTA and economic integration on trade value using HS (According to The International Convention on the Harmonized Commodity Description and Coding System separates 6 units. Korea: 10 units, US: 10 units, Japan: 9 units, China 8 units) 85's panel data of 45 countries trading with Korea from 1992 until 2013 by gravity model. It can be inferred how many impacts of Korea and China's FTA on throughput.

\section{Review of Trade between Korea and China}

Before examining trade between Korea and China, we reviewed degree of dependence upon foreign trade of Korea. Degree of dependence upon foreign trade of Korea in exports and imports occupied at 31.7\% and 29.1\% since in 2005, and it occupied at 89.8\% in 2011. After, it has been lower than before.

Table 1 shows degree of dependence upon foreign trade of Korea.

Table 2 shows percentage of export and import of Korea and China in 2014. Trade between Korea and China has been started since the establishment of diplomatic relations in 1992, until recently, China accounts for a greater and greater portion of Korea's external trade. Ratio of trade with China has been expanding continuously; it has been growth up to $25 \%$ in 2014.

In 2014, Korea's highest exports country was China, exports value was 145,288 million dollars, 25.4 percents. Korea’s highest imports country was China, imports value was 90,082 million dollars, 17.1 percents in 2014. On

Table 1. Degree of dependence upon foreign trade of Korea.

\begin{tabular}{|c|c|c|c|c|c|c|}
\hline \multicolumn{7}{|c|}{ million \$, \% } \\
\hline \multirow{2}{*}{ Year } & \multirow{2}{*}{ n. GDP } & \multicolumn{2}{|c|}{ Export } & \multicolumn{2}{|c|}{ Import } & \multirow{2}{*}{$\begin{array}{c}\text { Total } \\
\text { Degree }\end{array}$} \\
\hline & & Value & Degree & Value & Degree & \\
\hline 2005 & 898,000 & 284,419 & 31.7 & 261,238 & 29.1 & 60.8 \\
\hline 2006 & $1,011,000$ & 325,465 & 32.2 & 309,383 & 30.6 & 62.8 \\
\hline 2007 & $1,122,700$ & 371,489 & 33.1 & 356,846 & 31.8 & 64.9 \\
\hline 2008 & $1,001,700$ & 422,007 & 42.1 & 435,275 & 43.5 & 85.6 \\
\hline 2009 & 902,300 & 363,534 & 40.3 & 323,085 & 35.8 & 76.1 \\
\hline 2010 & $1,094,300$ & 466,384 & 42.6 & 425,212 & 38.9 & 81.5 \\
\hline 2011 & $1,202,700$ & 555,214 & 46.2 & 524,413 & 43.6 & 89.8 \\
\hline 2012 & $1,222,400$ & 547,870 & 44.8 & 519,584 & 42.5 & 87.3 \\
\hline 2013 & $1,304,300$ & 559,632 & 42.9 & 515,586 & 39.5 & 82.4 \\
\hline 2014 & $1,449,500$ & 572,665 & 39.5 & 525,515 & 36.3 & 75.8 \\
\hline
\end{tabular}

Data: Korea International Trade Association (KITA). 
Table 2. Percentage of export and import of Korea and China in 2014.

\begin{tabular}{|c|c|c|c|c|c|c|c|c|c|c|c|c|c|c|c|}
\hline \multicolumn{16}{|c|}{ million \$, \% } \\
\hline \multicolumn{8}{|c|}{ Korea } & \multicolumn{8}{|c|}{ China } \\
\hline \multicolumn{4}{|c|}{ Export } & \multicolumn{4}{|c|}{ Import } & \multicolumn{4}{|c|}{ Export } & \multicolumn{4}{|c|}{ Import } \\
\hline Rank & Country & Export & $\mathrm{p}$ & Rank & Country & Import & $\mathrm{p}$ & Rank & Country & Export & $\mathrm{p}$ & Rank & Country & Import & $\mathrm{p}$ \\
\hline 1 & China & 145,288 & 25.4 & 1 & China & 90,082 & 17.1 & 1 & USA & 396,063 & 16.9 & 1 & Korea & 190,286 & 9.7 \\
\hline 2 & USA & 70,285 & 12.3 & 2 & Japan & 53,768 & 10.2 & 2 & Hong Kong & 360,947 & 15.4 & 2 & Japan & 162,686 & 8.3 \\
\hline 3 & Japan & 32,184 & 5.6 & 3 & USA & 45,283 & 8.6 & 3 & Japan & 149,452 & 6.4 & 3 & USA & 153,131 & 7.8 \\
\hline 4 & Hong Kong & 27,256 & 4.8 & 4 & Saudi Arabia & 36,695 & 7.0 & 4 & Korea & 100,402 & 4.3 & 4 & Taiwan & 152,310 & 7.8 \\
\hline 5 & Singapore & 23,750 & 4.1 & 5 & Qatar & 25,723 & 4.9 & 5 & Germany & 72,731 & 3.1 & 5 & Germany & 104,776 & 5.3 \\
\hline 6 & Vietnam & 22,352 & 3.9 & 6 & Germany & 21,299 & 4.1 & 6 & Netherlands & 64,923 & 2.8 & 6 & Australia & 90,132 & 4.6 \\
\hline 7 & Taiwan & 15,077 & 2.6 & 7 & Australia & 20,413 & 3.9 & 7 & Vietnam & 63,618 & 2.7 & 7 & Malaysia & 55,771 & 2.8 \\
\hline 8 & India & 12,782 & 2.2 & 8 & Kuwait & 16,892 & 3.2 & 8 & UK & 57,133 & 2.4 & 8 & Brazil & 51,976 & 2.6 \\
\hline 9 & Indonesia & 11,361 & 2.0 & 9 & UAE & 16,194 & 3.1 & 9 & India & 54,237 & 2.3 & 9 & Saudi Arabia & 48,679 & 2.5 \\
\hline 10 & Mexico & 10,846 & 1.9 & 10 & Taiwan & 15,690 & 3.0 & 10 & Russia & 53,686 & 2.3 & 10 & Russia & 41,558 & 2.1 \\
\hline
\end{tabular}

Data: Korea International Trade Association (KITA).

the other hand, in 2014, Korea was ranked 4th exports county of China, exports value was 100,402 million dollars, 4.3 percents. China’s highest imports country was Korea, imports value was 190,286 million dollars, 9.7 percents in 2014.

We also checked the main export items of export and import to China in 2014. HS 85 code was occupied at first position in 35.25\% of exports, in 31.58\% of imports. Especially, Korea's top five export items to China (HS standard) were accounted around $90 \%$. Korea's export items to China were flat panel displays, semiconductor integrated circuits, petrochemicals, synthetic resins, intermediates, etc. Because of China Government had been conducted lower electronics and car industry policy from 2009, it caused largely growing needs about flat panel display, integrated circuits, semiconductors, auto parts, construction and heavy equipment in China.

On the other hand, Korea's import items to China were semiconductor integrated circuits, fine chemical raw materials, flat panel displays, power distributors and controllers. Korea's export items to China are consistent with Korea's import items to China significantly. It means industrial structure of Korea and China had been switched interindustry trade to intra-industry trade.

Therefore, in this study, first we prove the effects of trade index between Korea and China on throughput of them. And then we check the effects of FTA and economic integration on throughput of Korea and China by gravity model.

Table 3 shows Korea's 10 lists of export and import to China in 2014.

\section{Theoretical Consideration and Literature Review}

\subsection{Theoretical Consideration of Gravity Model}

The concept of gravity model is that the gravity between two objects in physics is proportional to mass, and inversely proportional to the distance. It has been applied for explaining to flow of economic exchanges between countries. In other words, it is the concept that economic exchanges between countries (e.g. trade) are inversely proportional to the distance. This gravity model was adopted international trade theory model from physics; it has been recognized to explain trade between countries and foreign direct investment in empirical parts [1].

In the 1960s, Poyhonen [2] stated quantitative analysis through gravity model, but it was not supported by economists at that time. Gravity model was very suitable model of an empirical analysis, and it produced successful results in quantitative analysis. But its theoretical basis was not on firm ground. However, after the 1970s, Anderson [3], Helpmanand Krugman [4], Bergstrand [5] [6] and Deardoff [7] proved gravity model equ- 
Table 3. Korea’s 10 lists of export and import to China in 2014.

\begin{tabular}{|c|c|c|c|c|c|}
\hline \multicolumn{6}{|c|}{10 million \$ } \\
\hline Rank & HS code & Export & Rate & Import & Rate \\
\hline 1 & 85 & $51,181,581$ & $35.23 \%$ & $28,444,356$ & $31.58 \%$ \\
\hline 2 & 90 & $20,350,744$ & $14.01 \%$ & $4,089,407$ & $4.54 \%$ \\
\hline 3 & 84 & $14,758,021$ & $10.16 \%$ & $10,460,562$ & $11.61 \%$ \\
\hline 4 & 29 & $13,520,686$ & $9.31 \%$ & $2,647,357$ & $2.94 \%$ \\
\hline 5 & 39 & $10,378,662$ & $7.14 \%$ & $2,069,058$ & $2.30 \%$ \\
\hline 6 & 27 & $7,799,278$ & $5.37 \%$ & 905,595 & $1.01 \%$ \\
\hline 7 & 87 & $7,435,484$ & $5.12 \%$ & $1,449,934$ & $1.61 \%$ \\
\hline 8 & 72 & $3,906,571$ & $2.69 \%$ & $8,903,105$ & $9.88 \%$ \\
\hline 9 & 74 & $1,618,688$ & $1.11 \%$ & 557,666 & $0.62 \%$ \\
\hline 10 & 28 & $1,121,353$ & $0.77 \%$ & 2,006,621 & $2.23 \%$ \\
\hline \multicolumn{2}{|c|}{ Total } & $145,287,701$ & $100 \%$ & $90,082,226$ & $100 \%$ \\
\hline
\end{tabular}

Data: Korea Customs Service; HS 85: Electrical machinery and equipment and parts thereof; sound recorders and reproducers, television image and sound recorders and reproducers, and parts and accessories of such articles; HS 90: Optical, photographic, cinematographic, measuring, checking, precision, medical or surgical instruments and apparatus; parts and accessories thereof; HS 84: Nuclear reactors, boilers, machinery and mechanical appliances; parts thereof; HS 29: Organic chemicals; HS 39: Plastics and articles thereof; HS 27: Mineral fuels, mineral oils and products of their distillation; bituminous substances; mineral waxes; HS 87: Vehicles other than railway or tramway rolling-stock, and parts and accessories thereof; HS 72: Iron and steel; HS 74: Copper and articles thereof; HS 28: Inorganic chemicals; organic or inorganic compounds of precious metals, of rare-earth metals, of radioactive elements or of isotopes.

ation can be deducted as basic international trade theory. This means that theoretical system and the foundation of gravity model were established.

Limits of quantitative analysis in traditional trade theory were shared among international scholars early. Gravity model was offered for solving that problem. In gravity model, it uses gross domestic product (GDP) or gross national income per capita (GDP per capita) like the mass of the law of gravity; it also uses transportation costs or geographic distance like the distance of the law of gravity. Gravity model has been continuously used in forecasting of international trade, quantitative analysis and factor analysis of determining trade, because simplicity of model setting and convenience of empirical analysis through real economic data. It also has high explanatory power considerably. In particular, Anderson and van Wincoop [8] showed gravity model has not only superior in empirical analysis, but also the theoretical foundation.

General Law of gravity equation is as follows [1].

$$
F_{i j}=G \times \frac{M_{i} M_{j}}{D_{i j}^{2}}
$$

In here, $F_{i j}$ is gravity between two objects, $M_{i} M_{j}$ is mass of two objects, $D_{i j}$ is distance between two objects, $G$ is gravitational constant.

Gravity model equation of gravity in international trade is as follows.

$$
T_{i j}=A \times \frac{Y_{i} Y_{j}}{D_{i j}}
$$

In here, $T_{i j}$ is trade value between two countries, $Y_{i} Y_{j}$ is GDP of two countries, $D_{i j}$ is distance between two countries, $A$ is proportional constant.

Trade value between two countries in above-mentioned equation has positive relationship with GDP; it has negative relationship with distance. This model can be arranged as follows.

$$
T_{i j}=\beta_{0}+\beta_{1} \ln Y_{i}+\beta_{2} \ln Y_{i}+\beta_{3} \ln D_{i j}
$$


There are several variations of gravity model in empirical analysis, but it has four common characteristics generally.

First, gravity model is applied for explaining trade between countries, and dependent variable is always trade related variable. Second, economic mass of export country and import country is generally measured by GDP, GNP, GDP per capita or GNP per capita. Third, distance is geographic distance between countries; it reflects transport costs as a variable of gravity model. And the distance is usually measured by straight distance between each country's economic center or capital. However, in some cases, it is not an accurate measurement. For example, if measuring distance between China and the other country using capital of China (Beijing), the result should be inaccurate. Because there are many economic centers except Beijing in China, and distance between Beijing to other economic centers is also too far. Four, dummy variable is used for analyzing variables like reciprocal trade agreement, language and borders.

The basic premise of gravity model in trade is that the trade value between two countries is proportional to the product of GDP, and inversely proportional to the distance between countries. Typically, the effects of each independent variable on trade value or it estimates by linear pane model using linear algebra for understanding the elasticity. In here, coefficient means the elasticity. Therefore, it means if each dependent variables change $1 \%$, how change export or trade value between countries. There are two estimation methods. Considering randomeffect model, fixed-effect model and Hausman test, if there are not relationship between dependent variables and error term (accept null hypothesis), it can select random-effect model. On the other hand, if there are relationship between dependent variables and error term (reject null hypothesis), it can select fixed-effect model.

\subsection{Previous Research}

The gravity model has been used by many researchers. In 1950, Viner [9] analyzed the effects of trade creation effect and customs union.

Taking his research, many scholars analyzed the effects of tariff and income. It was expanded to trade value in accordance with RTA. Beginning in the 2000s, it was studied on trade value and a property of trade structure more actively. In this process, they studied based on trade complementarity concepts, potential trade value and real trade value. In particular, they studied study on based on property of trade structure, analysis of theoretical trade value and real trade value through trade structure, identifying obstacle factors through trade structure, and study on extension of trade based on identified obstacle factors solve through RTA.

Egger [10] verified correlation of no-observable factors and explanatory variables by Hausman test. And based on that result, he studied the reason of why do not selecting random-effect model and about correlation of fixed-effect model.

Next, Elliott and Ikemoto [11] analyzed ASEAN free trade area (AFTA) by traditional gravity model adding trade conformity. They studied according to RTA, economic bloc between regional countries and offshore countries in traditional gravity model as dummy variables. In addition, they used trade index. Through this, they proved the more complementarity trade structure is, the higher trade value will be.

Pitigala [12] studied based on hypothesis natural trading partner and trade complementarity index (TCI) by gravity model. He established hypothesis that seven countries in South Asia satisfied condition of natural trading partner. And he determined South Asia free trade area (SAFTA) will have positive effects of expanding trade value based on analyzing trade complementarity index of South Asia's seven countries by gravity model.

After that, Baier and Bergstrand [13] argued to analyze methods using gravity model that there are three methods (ordinary least square (OLS), fixed-effect model and random-effect model), those have data-aware structures of different forms. They argued that there is a problem of endogeneity because general OLS can not control no-observable factors, so they used fixed-effect model and random-effect model because no-observable factors are deleted in those models.

Generally, when analyzing effects of RTA by gravity model, there are have doubtful points because it offsets the negative factors of trade diversion effect, and the positive factors of RTA. However, Streatfield [14] and Benedictis and Tajoli [15] asserted that RTA between similar trade structure countries causes trade creation effect because of maximizing effectiveness.

Streatfield [14] insisted there is a trade creation effect in trade change between similar export structure countries. Because if one of country is offshore country, there is high similarity of export structure, it causes difference of trade costs like tariff and logistics costs, so difference of productivity is not important. On the other hand, 
it causes low difference of trade costs like tariff and logistics costs, because it causes a competition even low difference of productivity.

Benedictis and Tajoli [15] argued that there are trade creation effects in industries of sharp competition because transfer of technique through RTA, spillover effect of technology and knowledge cause effect of a sharp increase in productivity. But, existing fixed-effect model can not estimate the coefficient of distance variable because it is not change in accordance with time. And there is a problem of the endogeneity among the variables of unchanging in accordance with time. (e.g. individual effects through historical or cultural backgrounds, and dummy variable of same language in each country etc.)

One of an important flow of empirical analysis by gravity model is about analysis of effects of trade agreement like RTA and FTA. Frankel [16] assumed the effects of RTA on trade value between countries adding new dummy variables like Asia Pacific Economic Cooperation (APEC), North American Free Trade Agreement (NAFTA) and Mercado Comúndel Sur (MERCOSUR). In a similar way, Garman and Debora [17] also investigated the effects of Latin America's RTA (e.g. Latin American Integration Association; LAIA, Andean Pact, Central American Common Market; CACM) on regional trade value by gravity model. In addition, Wall [18] analyzed for estimating trade patterns of US and economic costs of protective trade using limiting dependent variables as trade value among US and other countries.

Studying on analyzing decision factors of international trade using gravity model containing explanatory variables based on researchers, period and target countries made variety gravity models. However, except basic gravity model, there is not a model that all countries can be applied to gravity model.

Many common existing studies analyzed effects of RTA as separating trade creation effect and trade diversion effect. However, we analyzed not only trade creation effect between countries utilizing the existing variables, but also effects of each variable considering trade index as TCI, ESI and export and import price index.

\section{Empirical Analysis}

\subsection{Model Selection and Data}

Based on previous research, we set up an equation. In this equation, all the variables have been expressed in their natural logarithm form because all variables have differentcriteria; it needs to natural logarithm for data log-normal distribution.

$$
\begin{aligned}
\ln \operatorname{Trade}_{i j, t}= & \beta \ln \operatorname{Dist}_{i j}+\beta \ln \left(G D P_{i} \times G D P_{j}\right)_{t}+\beta \ln \left(\text { Pop }_{i} \times \text { Pop }_{j}\right)_{t} \\
& +\beta \ln T C I_{i j, t}+\beta \ln E S I_{i j, t}+\beta \ln \text { Price }_{i j, t}+F T A_{i j}(\text { dummy } 1) \\
& +\operatorname{ASEAN}_{i j}(\text { dummy } 2)+E U_{i j}(\text { dummy } 3)+\epsilon_{i j}
\end{aligned}
$$

In here, Trade $_{i j, t}$ is trade value (export + import) between Korea and the other country, Dist ${ }_{i j}$ is distance between Korea and its trade partner countries, capital to capital (in kilometers), $G D P_{i}$ and $G D P_{j}$ are Korea's GDP, Korea's trading partner countries' GDP, $P_{0} p_{i}$ and $P_{0} p_{j}$ are Korea's population and Korea's trading partner countries' population, $T C I_{i j, t}$ is index of trade complementarity between Korea and the other country, $E S I_{i j, t}$ is export similarity index between Korea and the other country, Price $_{i j, t}$ is export and import price index between Korea and the other country, $F T A_{i j}$ is if country $j$ is FTA with Korea, the value is 1 ,otherwise 0 , $A S E A N_{i j}$ is if country $j$ is ASEAN +3 member, the value is 1,otherwise 0 (dummy variables), $E U_{i j}$ is if country $j$ is EU member, the value is 1 , otherwise 0 (dummy variables).

The model is used for the balanced panel data over the time period of 1992-2013 which generated 990 observations. Basic statistical tests are performed on the data as given in Table 4; the correlation between variables is also found and given in the Table 5 . For this purpose, 45 countries each year are considered over the time period of 22 years from 1992 to 2013. This means that these 45 countries are considered every year, thus generating balanced panel data.

Data sources for our empirical tests are as follow:

Data on the basic variables of economic and population are obtained from IMF, data on the basic variables of trade index are obtained from UN, data on the distance is obtained from website; http://www.timeanddate.com

Division of commodity for analyzing export and import price index was distinguished by 2 units of HS (Harmonized System) code. 
Table 4. Descriptive statistics of the variables.

\begin{tabular}{ccccc}
\hline & \multicolumn{3}{c}{$\mathrm{N}=990$} & \\
\cline { 2 - 4 } & Mean & Std. Dev. & Min & 26.157 \\
Trade & 20.809 & 2.041 & 14.509 & 9.818 \\
Dist & 8.871 & 0.477 & 6.863 & 46.480 \\
GDP & 42.177 & 2.834 & 34.027 & 58.347 \\
Pop & 44.759 & 4.168 & 39.071 & 2.878 \\
TCI & 0.467 & 0.682 & -1.302 & 0.178 \\
ESI & -0.074 & 0.058 & -0.157 & 51.430 \\
Price & 46.646 & 1.920 & 41.525 & \\
\hline
\end{tabular}

Table 5. The correlation results of the variables used in the model.

\begin{tabular}{|c|c|c|c|c|c|c|c|c|c|c|}
\hline & Trade & Dist & GDP & Pop & TCI & ESI & Price & FTA & ASEAN & $\mathrm{EU}$ \\
\hline Trade & 1 & & & & & & & & & \\
\hline Dist & $-0.291^{* *}$ & 1 & & & & & & & & \\
\hline GDP & $0.161^{* *}$ & -0.039 & 1 & & & & & & & \\
\hline Pop & $0.586^{* *}$ & $-0.117^{* *}$ & $-0.541^{* *}$ & 1 & & & & & & \\
\hline TCI & 0.041 & $-0.231^{* *}$ & -0.049 & -0.051 & 1 & & & & & \\
\hline ESI & $0.292^{* *}$ & $-0.255^{* *}$ & $0.159^{* *}$ & $-0.079^{* *}$ & $0.532^{* *}$ & 1 & & & & \\
\hline Price & $0.761^{* *}$ & 0.022 & $0.415^{* *}$ & $0.304^{* *}$ & $-0.076^{* *}$ & $0.327^{* *}$ & 1 & & & \\
\hline FTA & $0.207^{* *}$ & -0.017 & $0.089^{* *}$ & 0.030 & $-0.410^{* *}$ & $0.065^{* *}$ & $0.267^{* *}$ & 1 & & \\
\hline ASEAN & $0.358^{* * *}$ & $-0.726^{* *}$ & 0.017 & $0.059^{*}$ & $0.0258^{* *}$ & $0.2883^{* *}$ & $0.063^{*}$ & $0.128^{* *}$ & 1 & \\
\hline EU & $0.067^{* *}$ & $0.323^{* *}$ & $0.543^{* *}$ & $-0.276^{* *}$ & $-0.249^{* *}$ & $0.026^{*}$ & $0.336^{*}$ & 0.017 & $-0.423^{* *}$ & 1 \\
\hline
\end{tabular}

${ }^{*} p<0.1,{ }^{* *} p<0.05$.

We analyzed correlation analysis for identifying multicollinearity problem among variables in the following Table 5. As a result, there is relatively high correlation between trade and population variable, but we used these variables because it is a low correlation as a whole.

\subsection{Results of Analysis}

We compared with TCI of Korean's major trading partners (China, Germany, India, Indonesia, USA) because if deducting TCI between Korea and China, there is not a reference point. China achieved high marks of 1.3235 in TCI. The results of other are shown in Table 6. Of course, even though the relative comparison, it has policy implications because Korea aims to increase trade value through FTA with China. Therefore, it has important implications of priority for practical expanding trade in RTA negotiations.

In ESI, Table 7 shows Korea and China's export similarity is almost the same as 0.997 . These high ESI, it is expected to collide in many commodities after Korea and China have signed FTA. Therefore, it is necessary to prepare that the strategy for activation of trade value. The higher ESI, the higher efforts of increasing efficiency between industries, it causes expanding export. Therefore, we can expect that tariff elimination of Korea-China FTA has effects on increasing efficiency between industries based on short term.

Generally, panel data that includes property of cross-section data and time series data connotes more information and volatility of variables. Therefore, we analyzed with fixed effects model (FE) and random effects model (RE) utilizing characteristic of panel data. After that, we estimated the results after choosing an appropriate 
Table 6. Trade complementarity index of Korea’s main trading partners in 2013.

\begin{tabular}{ccccc}
\hline China & Germany & India & Indonesia & United States \\
\hline 1.902 & 0.885 & 0.530 & 0.819 & 1.097 \\
\hline
\end{tabular}

Table 7. Export similarity index of Korea’s main trading partners in 2013.

\begin{tabular}{ccccc}
\hline China & Germany & India & Indonesia & United States \\
\hline 0.997 & 0.932 & 0.898 & 0.908 & 0.932 \\
\hline
\end{tabular}

model through Hausman test. Also, we analyzed effects on FTA and economic integration using ordinary least square (OLS) that used in most previous research.

One of the assumptions of the classical linear regression model is that there is no heteroskedasticity. Breaking this assumption means that the Gauss-Markov theorem does not apply, meaning that OLS estimators are not the best linear unbiased estimators (BLUE) and their variance is not the lowest of all other unbiased estimators. Therefore, in this study, we verified heteroskedasticity through White's heteroskedasticity-consistent estimator $(p=0.0000)$, and to complement this, we executed analysis by generalized least squares (GLS).

However, because GLS has limits that can not consider individual characteristic and time characteristic as the strength of panel data, based on property of panel data, we analyzed fixed effect model and random effect model. After that, we choose an appropriate model by Hausman test. The result of the test, fixed effect model was appropriate because a null hypothesis is rejected $(p=0.008)$.

The results of analysis including OLS, GLS, FE and RE are shown in Table 8.

Gravity model was suitable for explaining trade between Korea and other country because the OLS model, FE model and RE model were responsible for $84 \%, 76 \%$ and $81 \%$ of the subject (adjusted R-squared, 0.840, 0.758 and 0.808 and every $p=0.0000$ ). Distance variable in OLS model and GLS model were not same to a basic assumption of gravity model that the farther distance is, the lower trade value will be because it had a positive correlation. A $1 \%$ receding between Korea and other country was found to increase the trade value about $0.137 \%$ and $0.149 \%$. In here, we can find the reason of this results because containership maximization, port automation including container terminals and improvement of cargo working etc. TCI, ESI and export and import price index had statistically significant positive correlations. FTA, ASEAN and EU contributed expanding trade value through trade creation effects because they also had statistically significant positive correlations. These results were same to a basic assumption of gravity model that the bigger economic scale is, the higher trade value will be.

On the other hand, TCI had not statistically significant correlations. It means that tariff elimination, effect of tariff lowering and price elasticity of import demand are more effects on trade value than trade complementarity between Korea and other countries. FTA and economy integration variables also had statistically significant correlations. It means that it becomes the trade creation effects in region because expanding trade through eliminating trade barriers as a region country.

\section{Conclusions}

In the rapidly changing global trade environment, FTA and economic integration for building stable trade relations are actively being pursued. In order to respond environmental change and construct stable trade environment, Korea has contracted free trade agreements continuously.

According to global environment change, trade patterns and impact analysis are important tasks for growth through trade, and it has been studied about the impacts of trading patterns, economic integration and FTA on trade value among the countries using gravity model in specific business parts. However, in this study, not only effects of FTA and economic integration, but also effects of trade index and elimination of tariffs on trade value among the countries use the expanded gravity model.

We analyzed the impacts of FTA and economic integration on trade value using HS 85's panel data of 45 countries trading with Korea from 1992 until 2013 by gravity model.

We used trade value of trade between the two countries as dependent variables, GDP, distance, trade complementarity index (TCI), export and import price index (ESI) and export and import price index as independent 
Table 8. Results of empirical analysis.

\begin{tabular}{ccccc}
\hline & OLS & GLS & FE & RE \\
\hline Intercept & $-20.906^{* * *}(1.243)$ & $-23.283^{* * * *}(0.787)$ & $-28.027^{* * *}(3.640)$ & $-17.375^{* * *}(3.739)$ \\
Dist & $0.137(0.099)$ & $0.149^{* * *}(0.065)$ & Omitted (omitted $)$ & $-0.419(0.279)$ \\
GDP & $0.229^{* * *}(0.023)$ & $0.244^{* * *}(0.013)$ & $0.435^{* * *}(0.074)$ & $0.329^{* * *}(0.050)$ \\
Pop & $0.327^{* * *}(0.015)$ & $0.335^{* * *}(0.009)$ & $0.522^{* * *}(0.065)$ & $0.397^{* * *}(0.035)$ \\
TCI & $0.139^{* * *}(0.058)$ & $0.228^{* * * *}(0.035)$ & $0.045(0.053)$ & $-0.011(0.0459)$ \\
ESI & $2.267^{* * *}(0.785)$ & $0.497(0.583)$ & $4.441^{* * *}(0.806)$ & $4.062^{* * *}(0.784)$ \\
Price & $0.339^{* * *}(0.033)$ & $0.360^{* * *}(0.020)$ & $0.154^{* * *}(0.039)$ & $0.219^{* * *}(0.032)$ \\
FTA & $0.178^{* * *}(0.082)$ & $0.104^{* *}(0.043)$ & $0.032^{*}(0.0463)$ & $0.068^{*}(0.045)$ \\
ASEAN & $1.677^{* * *}(0.115)$ & $1.826^{* * *}(0.072)$ & $0.232^{* * *}(0.222)$ & $0.652^{* * *}(0.192)$ \\
EU & $0.419^{* * *}(0.079)$ & $0.473^{* * *}(0.063)$ & $0.533^{* * *}(0.065)$ & $0.535^{* * *}(0.061)$ \\
$\mathrm{R}^{2}$ & 0.840 & & 0.758 & 0.808 \\
Hausman $^{2}(p$-value $)$ & & & $20.89(0.008)$
\end{tabular}

${ }^{*} p<0.1,{ }^{* *} p<0.05,{ }^{* * *}<0.01$; ( ) is Std. Dev. In FE, Dist variable was omitted because it has same variables each year.

variables, and FTA, ASEAN, EU as dummy variables. We used trade value of trade between the two countries as dependent variables, GDP, distance, TCI, ESI and export and import price index as independent variables, and FTA, ASEAN, EU as dummy variables. The effects of FTA and economic integration on throughput of Korea and China are as follows.

First, trade value has trade patterns due to the market size (GDP). It is accorded with the basic gravity model hypothesis. In other words, an increase in GDP between Korea and other country was found to increase the trade value. But in distance, the results of analysis are different in each analytic method. The concept of a distance is different than before in trade because of containership maximization, port automation and improvement of cargo working, etc.

Second, trade indexes (ESI, price index) have the effects of changing throughput in Korea except TCI. That is to say, if construct self-sufficient economic system in the region through regional trade agreement, in order to protect participation and competition of the countries in the offshore, tariff will not be a trade barrier between nations and it will be a trade barrier between regional countries and offshore countries. Also, this result is expected because we use 2-digit HS code (HS 85) among the 6-digit HS code. There is a lack of data for reflecting the effects. Therefore, it will have to be reflected in future research.

As a result, we can conclude that there is comparability between China and Korea because ESI is 1.007. FTA will have much possibility to produce trade conflict with China in Korea. So FTA signed some agreements in many trade areas in order to minimize the impact of conflicts by government and enterprise. It also needs manufacturing that could judge advantageous strategy for Korean sphere of trade. The main industry in Korea should find sally port from Chinese competitive priced advantage, especially competitive price and abundant manpower resources. These factors make Korean become more and more dependent on China in export. Nowadays, more and more transnational enterprises choose China as the industrial complex for strengthening price competitiveness and market, so China upgrades industrial structure rapidly. Therefore, Korean strategy should focus on increasing exports to China. In manufacturing, it also needs more details on sensitive items and needs to find an approach to abolish customs barriers or reduce tariffs on competitive business project. On the other hand, for non-competitive items, it needs to try to related strategies to adjust direction of smooth structure.

Third, FTA proved statistical significance. There are the implications in Korea-China FTA signed in 2015. It can be judged that Korea-China FTA is important in the change of world economic; 1) to seize opportunities of growing Chinese market utilization, 2) to maintain dynamics and reinforcement of Korean economy, 3) to build favorable environment in separation of industries of Northeast Asia, etc.

As China, Korea-China FTA will seem to be based on East Asian economic integration. Because Korea is a 
manufacturing power, it will extend trade effectively unlike existing FTA with neighboring countries or small economics. It also will offset negative effects through Korea-US FTA of China. In addition, because Chinese tariff is higher than the other countries and trade value between Korea and China has an extensive scale, Korea-China FTA effect is expected more than 2\% of the GDP growth through increasing Korea's exports significantly. General manufacturing (e.g. car industry, fiber industry and petrochemical industry) export effect will be large, in the case that agricultural products import will be higher effect twice than export. Moreover, macroeconomic effects of Korea-China FTA will be expected larger than Korea-the other countries (e.g. Korea-EU, Korea-ASEAN and Korea-US)

In order to obtain such economic combination's effects, although there are some deference between the government and enterprise on industrial category, they both need this direction as oriented (for ensuring source technology and core technology, technical cooperation and expansion of R \& D investment; for selecting and focusing on high value added and differentiated products; for developing new products, new engineering and new design; for improving technical level on beaches, materials and parts; for strengthening cooperation between large enterprises and small enterprises; for promoting continuous and smooth structural adjustment and for needing institutional supports).

Finally, economic integration variables are indicated positive in the trading patterns and throughput. It can say there are trade creation effects. Therefore, it requires effective countermeasures like increasing fleet etc. in economic integration of the trade creation effects for trade revitalization.

This study analyzed the result of Korean and Chinese FTA. It is not the truth because this FTA is a new start and we estimate right data through this theory. And only by observing HS 85 code to conclude Korean trade as whole is also unscientific. These parts should give much supplement in further research. For accurate analysis, study should analyze various factors, such as exchange rate, world economy (like BDI), and port factor (like port tariff).

\section{References}

[1] Sun, L. and Reed, M.R. (2010) Impacts of Free Trade Agreements on Agricultural Trade Creation and Trade Diversion. American Journal of Agricultural Economics, 92, 1351-1363. http://dx.doi.org/10.1093/ajae/aaq076

[2] Poyhonen, P. (1963) A Tentative Model for the Volume of Trade between Countries. Weltwirtschaftliches Archiv, 90, 93-100. http://www.jstor.org/stable/40436776

[3] Anderson, J.E. (1979) A Theoretical Foundation of the Gravity Model. American Economic Review, 69, 106-116. http://www.jstor.org/stable/1802501

[4] Helpman, E. and Krugman, P.R. (1985) Market Structure and Foreign Trade: Increasing Returns, Imperfect Competition, and the International Economy. MIT Press, Cambridge.

[5] Bergstrand, J.H. (1985) The Gravity Equation in International Trade: Some Microeconomic Foundations and Empirical Evidence. Review of Economics and Statistics, 67, 474-481. http://dx.doi.org/10.2307/1925976

[6] Bergstrand, J.H. (1989) The Generalized Gravity Equation, Monopolistic Competition, and the Factor-Proportions Theory in International Trade. Review of Economics and Statistics, 71, 143-153. http://dx.doi.org/10.2307/1928061

[7] Deardorff, A. (1998) Determinants of Bilateral Trade: Does Gravity Work in a Classical World? In: Frankel, J., Ed., The Regionalization of the World Economy, University of Chicago Press, Chicago.

[8] Anderson, J.E. and van Wincoop, E. (2003) Gravity with Gravitas: A Solution to the Border Puzzle. American Economic Review, 93, 170-192. http://www.jstor.org/stable/3132167 http://dx.doi.org/10.1257/000282803321455214

[9] Viner, J. (1950) The Customs Union. Carnegie Endowment for International Peace, Washington DC.

[10] Egger, P. (2002) An Econometric View on the Estimation of Gravity Models and the Calculation of Trade Potentials. World Economy, 25, 297-312. http://dx.doi.org/10.1111/1467-9701.00432

[11] Elliott, R.J.H. and Ikemoto, K. (2003) A FTA and the Asian Crisis: Help of Hindrance to ASEAN Intra-Regional Trade? Asian Economic Journal, 18, 1-23. http://dx.doi.org/10.1111/j.1467-8381.2004.00179.x

[12] Pitigala, N. (2005) What Does Regional Trade in South Asia Reveal about Future Trade Integration? Some Empirical Evidence. World Bank WP, 3497, World Bank. http://dx.doi.org/10.1596/1813-9450-3497

[13] Baier, S.L. and Bergstrand, J.H. (2007) Do Free Trade Agreements Actually Increase Members’ International Trade? Journal of International Economics, 71, 72-95. http://dx.doi.org/10.1016/j.jinteco.2006.02.005

[14] Streatfeild, J.E.J. (2003) An Examination of Regional Trade Agreements: A Case Study of the EC and the East African 
Community. TRALAC Working Paper, 11/2003, Trade Law Centre for Southern Africa. http://www.tralac.org/wp-content/blogs.dir/12/files/2011/uploads/WP_112003_Streatfeild.pdf

[15] Benedictis, L.D. and Tajoli, L. (2003) Economic Integration, Similarity and Convergence in the EU and CEECS Trade Structure. Kites Working Papers. http://www.etsg.org/ETSG2003/papers/debenedictis.pdf

[16] Frankel, J.A. (1997) Regional Trading Blocs in the World Economic System. Institute for International Economics, Washington DC. http://dx.doi.org/10.7208/chicago/9780226260228.001.0001

[17] Garman, G. and Debora, G. (1999) Economic Integration in the Americas: 1975-1992. The Journal of Applied Business Research, 14, 1-12. http://dx.doi.org/10.19030/jabr.v14i3.5698

[18] Wall, J.H. (2000) Using the Gravity Model to Estimate the Costs of Protection. Federal Reserve Bank of St Louis Review, 1, 33-40. http://research.stlouisfed.org/publications/review/99/01/9901hw.pdf 